Article

\title{
Removal of Pollutants from an AMD from a Coal Mine by Neutralization/Precipitation Followed by "In Vivo" Biosorption Step with the Microalgae Scenedesmus sp.
}

\author{
Karine Batista dos Santos, Vítor Otacílio de Almeida, Jéssica Weiler \\ and Ivo André Homrich Schneider* \\ Laboratório de Tecnologia Mineral e Ambiental, Programa de Pós-Graduação em Engenharia de Minas, \\ Metalúrgica e de Materiais, Escola de Engenharia, Universidade Federal do Rio Grande do Sul, \\ Porto Alegre 90040-060, Brasil; karineebatista@gmail.com (K.B.d.S.); vitor01almeida@hotmail.com (V.O.d.A.); \\ jessica.weiler18@gmail.com (J.W.) \\ * Correspondence: ivo.andre@ufrgs.br; Tel.: +55-51-3308-7882
}

Received: 24 June 2020; Accepted: 4 August 2020; Published: 12 August 2020

\begin{abstract}
This work evaluates the benefits of a complementary treatment step of acid mine drainage (AMD) using the algae Scenedesmus sp. in terms of algae biomass production, residual metal removal, and the toxicity of the discharged water. Conventional treatment by neutralization/precipitation of an AMD from a coal mine in Brazil was conducted with $\mathrm{Ca}(\mathrm{OH})_{2}$ at $\mathrm{pH}$ 8.7. Algal growth studies were performed in the treated AMD, with and without a nutrient supply. The raw effluent and treatments were compared in terms of residual concentration of metals and sulfate, conductivity, and toxicity with the Allium cepa and Daphnia magna test organisms. The results show that the conventional treatment allowed a major metal removal, reduction in the conductivity, and good indices in the toxicological parameters evaluated. The biosorption with in vivo microalgae improved the quality of the effluent for residual metals. No significant toxicity was observed to Allium cepa in all treatments performed, while the Daphnia magna test indicated a reduction in toxicity after the biosorption step. It was concluded that algae growth can be carried out in treated mine waters, providing algae biomass and helping to achieve the standards for water discharge.
\end{abstract}

Keywords: acid mine drainage; conventional treatment; biosorption; algae; metal removal; toxicity

\section{Introduction}

Active chemical treatment by neutralization has been widely applied by the coal mining industry to prevent the damages caused by acid mine drainage. The process involves the addition of alkaline reagents to increase the $\mathrm{pH}$ and precipitate the dissolved metals as hydroxides [1-3]. Recently, Skousen et al. [4] pointed out six chemicals commonly used to treat AMD: limestone $-\mathrm{CaCO}_{3}$, hydrated lime $-\mathrm{Ca}(\mathrm{OH})_{2}$, pebble quicklime $-\mathrm{CaO}$, soda ash $-\mathrm{Na}_{2} \mathrm{CO}_{3}$, caustic soda $-\mathrm{NaOH}$, and ammonia- $\mathrm{NH}_{3}$. Considering the acidic mine water treatment plants in Brazil, the most commonly used neutralizing reagent is hydrated lime, raising the $\mathrm{pH}$ to 8.7. Calcium chemicals are preferred since they are cheaper and allow the partial removal of the amount of sulfate ions present in the wastewater [5].

This practice was validated by recent studies applying the reagents $\mathrm{Ca}(\mathrm{OH})_{2}$ and $\mathrm{NaOH}$ at $\mathrm{pH} 7.0$ and 8.7 to treat acid mine drainage from a coal mine [6,7]. All neutralizing treatments resulted in a satisfactory reduction in the metal concentration, with the best results achieved using $\mathrm{Ca}(\mathrm{OH})_{2}$ at $\mathrm{pH}$ 8.7, although $\mathrm{Mn}$ and As remained above or near the maximum limits for discharge according to the Brazilian legislation. Additional treatment steps can also be applied for AMD control when 
greater treatment efficiency is needed [3]. Studies suggested the use of algae to remove residual metals from AMD [7-9], since they can act as metal accumulators through bioaccumulation (active mechanism) and/or biosorption (passive mechanism). Algae species of genera such as Spirulina, Chlorella, Scenedesmus, Cladophora, Oscillatoria, Anabaena, and Phaeodactylum tricornutum showed capacity to remove a considerable content of metals from AMD [9]. Algae ponds could also generate a possible biomass use [10] and, in particular, the Scenedesmus genera are greatly used for the production of biodiesel, biogas, and proteins [11,12].

Indeed, there is a growing trend in the different uses of treated AMD. Many of the studies aim to integrate AMD treatment systems with the recovery of dissolved metals and the synthesis of products [13-22]. However, there are considerably fewer works concerning the use of discharged water. The main initiatives are for water reuse in the industrial systems $[5,23,24]$, as a resource for drinking water [22], to produce electricity [25], and for algae growth [7,26-28]. We should point out that the study of Pereira et al. [7] was carried out with the Scenedesmus sp. strain in treated coal mine water, but not exploring the total algae growth capacity, given that there was a lack of nutrients in the system, mainly in terms of nitrogen and phosphorus.

The objective of this work was to evaluate the benefits of an additional step in AMD treatment by growing the algae Scenedesmus sp. in vivo. The water substrate was attained from a coal mine in south Brazil after conventional treatment by neutralization/precipitation with $\mathrm{Ca}(\mathrm{OH})_{2}$ at $\mathrm{pH}$ 8.7. The treated effluent was subjected to algal growth both with and without the addition of nutrients. The quality of the treated water was analyzed in terms of conductivity, metals, and sulfate concentration, as well as in terms of toxicological effects for Allium cepa and Daphnia magna.

\section{Materials and Methods}

\subsection{AMD Sample}

The sample of AMD used in this work was provided by a coal mining company located in the municipality of Figueira, northeast of the State of Paraná, Brazil $\left(23^{\circ} 49^{\prime} 15^{\prime \prime}\right.$ S; $50^{\circ} 25^{\prime} 50^{\prime \prime}$ W). The coal seams are explored in the Paraná Basin and are part of the Permian Rio Bonito Formation [29]. Coal waste is highly associated with iron sulfides, with a content of pyrite ranging up to $15 \%$. Reject surface dumps are also associated with toxic pollutants such as $\mathrm{Zn}, \mathrm{Mn}, \mathrm{Pb}$, and $\mathrm{As}$, which are commonly dissolved in water when the $\mathrm{pH}$ decreases [30].

\subsection{AMD Treatments}

The conventional treatment of AMD was conducted based on the treatment carried out by Brazilian mining companies. First, the $\mathrm{pH}$ was raised to 8.7 by adding the alkaline reagent (calcium hydroxide $-\mathrm{Ca}(\mathrm{OH})_{2}$ ) under stirring and monitoring the $\mathrm{pH}$ with a $\mathrm{pH}$ meter, followed by precipitation of the metals as hydroxides. The supernatant was filtered and then separated for the additional treatment with algae.

The algae species selected was Scenedesmus sp. due to its known metal absorption capacity [9,31], and its use as a biofuel resource [11,12]. Microalgae cultures for inoculation were maintained in $1000 \mathrm{~mL}$ Erlenmeyer flasks with the Guillard modified culture medium at $25^{\circ} \mathrm{C}$ and 3910 lux and were used when the growth reached the exponential phase. Two scenarios for Scenedesmus sp. growth in the treated AMD were observed: (a) without addition of nutrients; and (b) with the addition of $0.1 \%$ (volume) of the macronutrients supply of Guillard medium composed of: $36.76 \mathrm{~g} \mathrm{~L}^{-1}$ of $\mathrm{CaCl}_{2} \cdot 2 \mathrm{H}_{2} \mathrm{O}$, $36.97 \mathrm{~g} \mathrm{~L}^{-1}, \mathrm{MgSO}_{4} .7 \mathrm{H}_{2} \mathrm{O}, 12.6 \mathrm{~g} \mathrm{~L}^{-1}$ of $\mathrm{NaHCO}_{3}, 8.71 \mathrm{~g} \mathrm{~L}^{-1}$ of $\mathrm{K}_{2} \mathrm{HPO}_{4}, 85.01 \mathrm{~g} \mathrm{~L}^{-1}$ of $\mathrm{NaNO}_{3}$ and $28.42 \mathrm{~g} \mathrm{~L}^{-1}$ of $\mathrm{Na}_{2} \mathrm{SiO}_{3} .7 \mathrm{H}_{2} \mathrm{O}$ [32]. Erlenmeyer flasks $(250 \mathrm{~mL})$ containing AMD and $1 \%$ algae inoculum were incubated on an orbital shaker (model CT-712RN Cientec) at $125 \mathrm{rpm}, 27.5^{\circ} \mathrm{C}$, with a photoperiod of $16 \mathrm{~h}$ /day under illumination with a light intensity of 6200 lux. Dry weight and optical density (OD) were measured daily to determine the microalgal growth and relationship between the dry weight and optical density. OD was measured at $570 \mathrm{~nm}$ wavelength (UV1100 spectrophotometer Pro-tools), 
and the dry matter was measured by filtering the samples through $0.7 \mu \mathrm{m}$ pre-weighted membranes, which were dried at $60{ }^{\circ} \mathrm{C}$ for $24 \mathrm{~h}$.

Thus, the samples (each one in triplicate) were submitted to physical-chemical and toxicological analyses, as illustrated in Figure 1.

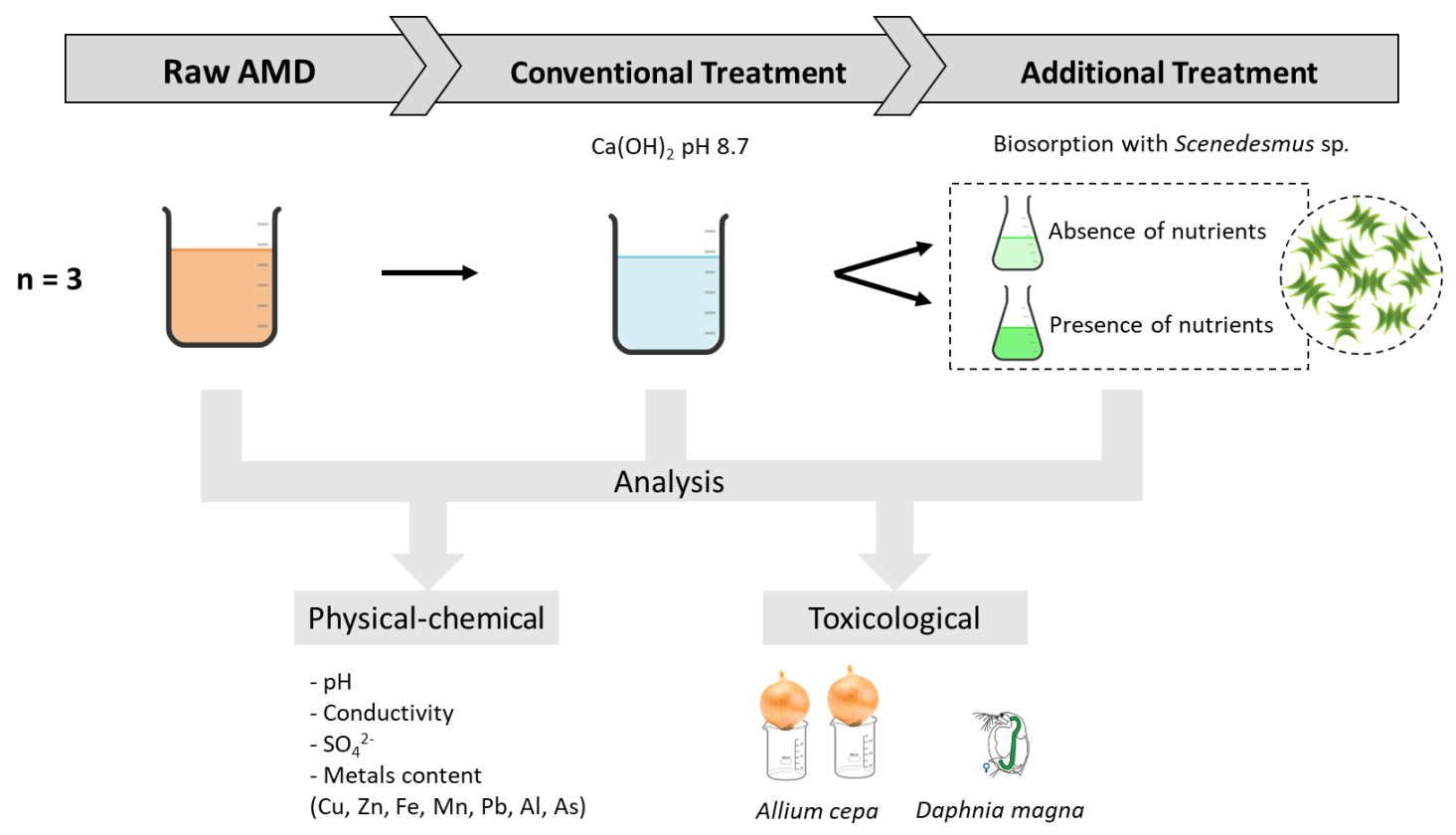

Figure 1. Illustrative scheme of this work, including the treatments and analysis performed.

\subsection{Physical-Chemical and Toxicological Analysis}

Raw AMD and treated waters were analyzed for $\mathrm{pH}$, conductivity and metals content $(\mathrm{Cu}, \mathrm{Zn}, \mathrm{Fe}$, $\mathrm{Mn}, \mathrm{Pb}, \mathrm{Al}, \mathrm{As}$ ), sulfate content, and toxicological tests with Allium cepa and Daphnia magna.

The $\mathrm{pH}$ of the suspension was measured using a bench $\mathrm{pH}$ meter (AKSO model 86505, São Leopoldo, Brazil). Electrical conductivity was measured using a Zetasizer (Malvern Panalytical, Malvern, UK). Metal analyses were carried out by sample preservation with $\mathrm{HNO}_{3}$ and by an issuing optical spectrophotometer with inductively coupled plasma (ICP-OES). The sulfate content was measured using the turbidimetric method. All analyses followed the procedures described in the "Standard Methods for Examination of Water and Wastewater" [33].

The Allium cepa root growth test was carried out with onions of the same origin and approximate sizes. The outer scales of the onions were removed and the bulb gently scraped. Bulbs were kept in touch with deionized water in beaker glasses for $24 \mathrm{~h}$ at room temperature to stimulate root growth. After this period, the bulbs were placed at each test condition and maintained in contact with the same for $72 \mathrm{~h}$ under the light and following the procedure of Fiskesjö [34]. The test was performed in triplicate and a control group was adopted using deionized water. The number, as well as the mass and the length of the three largest roots in each bulb, were measured. The results of the different tests conditions were compared with the control in terms of relative growth index (RGI) (Equation (1)), the inhibition index (II) (Equation (2)) and the germination index (GI) (Equation (3)). The phytotoxicity was considered when there was a significant decrease between the test and control groups:

$$
\begin{gathered}
R G I=\frac{L m}{L_{0}} \\
I I=\left(1-\frac{L m}{L_{0}}\right) \times 100
\end{gathered}
$$




$$
G I=\frac{G}{G_{0}} \times R G I \times 100
$$

where $L m$ is the average length of the roots in the samples, $L_{0}$ is the average length of the roots in the control, $G$ is the germination value in the samples, and $G_{0}$ is the germination rate in the control.

Acute toxicity tests for Daphnia magna microcrustaceans were performed in triplicate and in accordance with the Guideline for Testing of Chemicals using Daphnia sp. OECD 202 [35], using the statistical technique EPA 821-R2-012 [36]. This test assesses the immediate toxic effects of a sample on the mobility of this microcrustacean species and is based on the exposure of organisms to a series of dilutions of the sample for $48 \mathrm{~h}$. The effect on organisms is expressed by a loss of mobility. The result is calculated by a statistical procedure and represented by the concentration effect to $50 \%$ of the population (EC-50-48 h).

\subsection{Statistical Analysis}

The results were presented in terms of mean and standard deviation. Results were assessed using analysis of variance (ANOVA) with significance level $p$-value $<0.05$ and the Tukey test to compare the differences between averages.

\section{Results and Discussion}

Chemical parameters of the AMD used in this study, and the results of the AMD treated for each treatment in terms of $\mathrm{pH}$, conductivity, sulfates, and metals (iron, aluminum, manganese, zinc, lead, arsenic, and copper), are compiled in Table 1 . These results were compared with the current Brazilian environmental legislation, CONAMA 430/2011 [37].

Table 1. Characterization of acid mine drainage (AMD) after conventional treatment-neutralization/ precipitation with $\mathrm{Ca}(\mathrm{OH})_{2}$ at $\mathrm{pH} 8.7$-and additional treatment with growth of Scenedesmus sp. algae.

\begin{tabular}{|c|c|c|c|c|c|c|c|c|c|}
\hline & \multirow{2}{*}{\multicolumn{2}{|c|}{ Raw AMD }} & \multirow{2}{*}{\multicolumn{2}{|c|}{$\begin{array}{l}\text { Conventional Treatment } \\
\qquad \mathrm{Ca}(\mathrm{OH})_{2} \mathrm{pH} 8.7\end{array}$}} & \multicolumn{4}{|c|}{ Additional Treatment } & \multirow{3}{*}{$\begin{array}{c}\text { CONAMA } \\
430 / 2011\end{array}$} \\
\hline & & & & & \multicolumn{2}{|c|}{ Algae } & \multicolumn{2}{|c|}{$\begin{array}{c}\text { Algae + } \\
\text { Macronutrients }\end{array}$} & \\
\hline & Mean & sd & Mean & sd & Mean & sd & Mean & sd & \\
\hline $\mathrm{pH}$ & 2.33 & 0.15 & 8.7 & 0.0 & 5.55 & 0.21 & 5.75 & 0.7 & \\
\hline Conductivity $\left(\mathrm{mS} \mathrm{cm}^{-1}\right)$ & 7.79 & 0.02 & 5.28 & 0.07 & 4.84 & 0.08 & 4.34 & 0.10 & - \\
\hline $\mathrm{SO}_{4}^{2-}\left(\mathrm{mg} \mathrm{L}^{-1}\right)$ & 7410.40 & 36.94 & 2727.60 & 19.49 & 1325.75 & 5.59 & 1250.40 & 3.82 & - \\
\hline $\mathrm{Fe}\left(\mathrm{mg} \mathrm{L}^{-1}\right)$ & 611.38 & 5.11 & 0.90 & 0.02 & 0.08 & 0.11 & 0.05 & 0.07 & 15 \\
\hline $\mathrm{Al}\left(\mathrm{mg} \mathrm{L}^{-1}\right)$ & 269.37 & 11.67 & 0.08 & 0.08 & 0.24 & 0.33 & 0.30 & 0.43 & - \\
\hline $\mathrm{Zn}\left(\mathrm{mg} \mathrm{L}^{-1}\right)$ & 62.65 & 0.55 & 0.10 & 0.10 & 0.06 & 0.06 & 0.08 & 0.04 & 5 \\
\hline $\operatorname{Mn}\left(\mathrm{mg} \mathrm{L}^{-1}\right)$ & 37.98 & 0.36 & 1.54 & 0.40 & 0.46 & 0.27 & 0.45 & 0.11 & 1 \\
\hline $\mathrm{Pb}\left(\mathrm{mg} \mathrm{L}^{-1}\right)$ & 0.41 & 0.02 & 0.15 & 0.05 & 0.06 & 0.08 & 0.02 & 0.03 & 0.5 \\
\hline As $\left(\mathrm{mg} \mathrm{L}^{-1}\right)$ & 0.85 & 0.05 & 0.30 & 0.31 & 0.14 & 0.18 & 0.12 & 0.14 & 0.1 \\
\hline $\mathrm{Cu}\left(\mathrm{mg} \mathrm{L}^{-1}\right)$ & nd & - & nd & - & nd & - & nd & - & 1 \\
\hline Metal content * $\left(\mathrm{mg} \mathrm{L}^{-1}\right)$ & 982.64 & 15.16 & 3.07 & 0.75 & 1.03 & 0.28 & 1.02 & 0.73 & - \\
\hline
\end{tabular}

* Sum of the metals Fe, Al, Zn, Mn, Pb, As, and Cu. sd: standard deviation. nd: not detected. Database: Santos [38] and results partially published in Pereira et al. [7].

The conventional treatment was satisfactory considering the $\mathrm{pH}$ correction, $60 \%$ reduction in the sulfate content, and almost total removal of $\mathrm{Fe}, \mathrm{Al}$ and $\mathrm{Zn}$. However, for $\mathrm{Mn}$ and As, the treatment efficiency was not sufficient to achieve the limits stablished by the legislation. Thereafter, additional treatment with algae was investigated for polishing and removing the remaining metals. The AMD after conventional treatment was submitted to contact with Scenedesmus sp. and their growth was monitored over 10 days for each scenario in terms of biomass (Figure 2). 


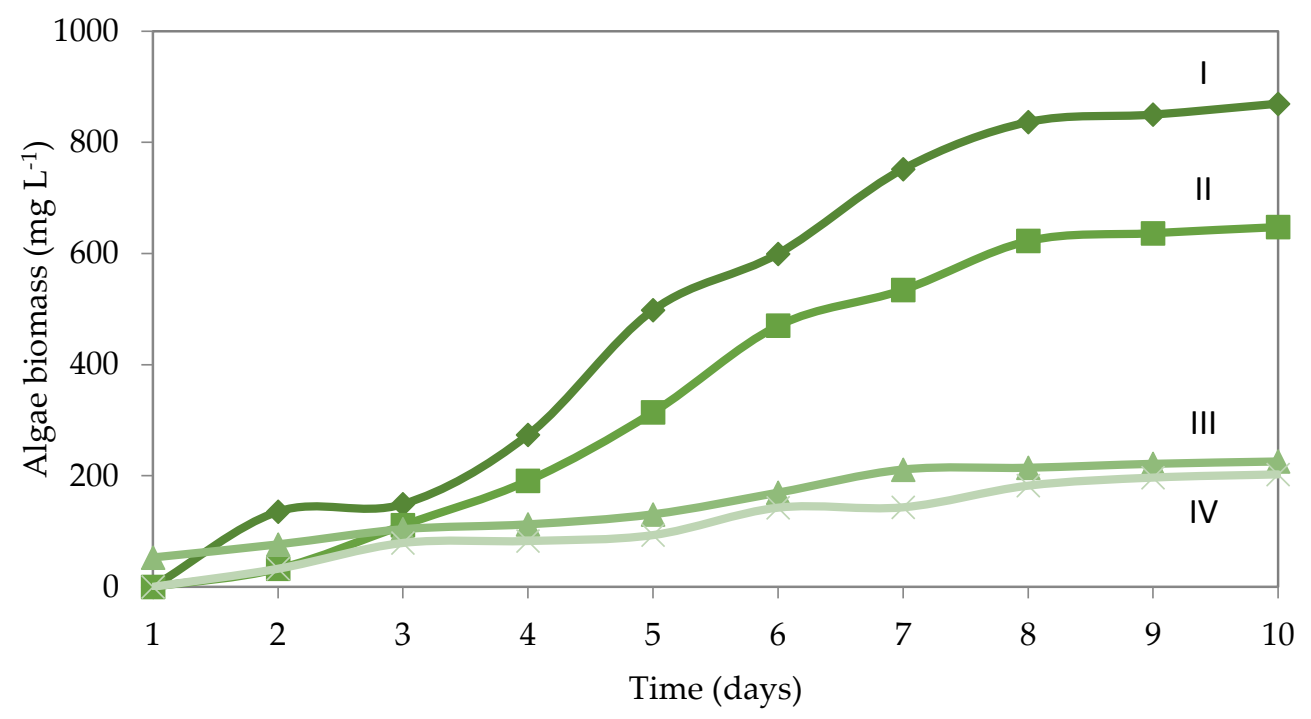

Figure 2. Growth of algae biomass as a function of time for Guillard medium-I; AMD after conventional treatment with nutrients-II; AMD after conventional treatment without nutrients-III; and for the control (water purified by reverse osmosis)-IV.

At the end of ten days of growth, $880 \mathrm{mg} \mathrm{L}^{-1}$ of algae biomass was achieved in the Guillard nutrients solution, $650 \mathrm{mg} \mathrm{L}^{-1}$ in the treated AMD with nutrient supply, $230 \mathrm{mg} \mathrm{L}^{-1}$ in the treated AMD without addition of nutrients, and $200 \mathrm{mg} \mathrm{L}^{-1}$ in distilled water. Algal growth in AMD was successful when nutrients were added, reaching values $(75 \%)$ close to those obtained in an ideal culture medium, in this case the Guillard medium. Without the addition of nutrients, the growth was similar to the control (water only).

After algal growth, the water quality parameters were even more satisfactory for conductivity, sulfates, and the remaining metals. The removal of Mn was effective, reaching values below that established for discharge in water resources in Brazil [37]. There was also a decrease in the concentration of arsenic, but this was still above the limits applied by the legislation.

The differences between the adopted treatment procedures are depicted in Figure 3 in terms of final sulfate concentration and metal content (sum of $\mathrm{Fe}, \mathrm{Al}, \mathrm{Zn}, \mathrm{Mn}, \mathrm{Pb}, \mathrm{As}$, and $\mathrm{Cu}$ ). It is possible to observe that the conventional treatment provides a partial removal of sulfates and an almost complete removal of these metals. Regarding sulfates, each treatment step allowed a statistically significant improvement, reaching the greatest efficiency with algae growth with the addition of nutrients. For metals, the same was observed, with the difference being that the addition of nutrients, with an increase in algae biomass production, did not provide a refinement. This may be because the metal removal is already quite high from the conventional treatment. The metal uptake was $8.9 \mathrm{mg} \mathrm{g}^{-1}$ of algae (in dry basis) in the case where no nutrients were added, similar to results obtained in other studies [39]. When nutrients were added, the mass of algae increased, but the removal of metals was almost the same, resulting in a metal uptake of $3.15 \mathrm{mg} \mathrm{g}^{-1}$ of algae, which is probably below the biosorption accumulation capacity of this Scenedesmus sp. The optimal conditions for the metal uptake by microalgae are due to many factors, including $\mathrm{pH}$, metal speciation, the initial concentration of metal ions, and the mass of algae present, with an adsorption limit [40].

In the present case, the approximate values in the residual concentration of metals with and without nutrients may be explained by the low concentration of metal ions in the effluent after the conventional treatment. After this treatment step, the sum of transition metals plus arsenic and aluminum is approximately $3 \mathrm{mg} \mathrm{L}^{-1}$. Considering the amount of algae biomass of $0.65 \mathrm{~g} \mathrm{~L}^{-1}$ in the treated AMD with nutrient supply, $0.23 \mathrm{~g} \mathrm{~L}^{-1}$ in the treated AMD without addition of nutrients, and literature data [40], the adsorption would fits in the beginning of the equilibrium curve plotted in the Cartesian plane, where there is a little variation of the residual pollutant in water solution with the 
increase in pollutant accumulation onto the biomass-assuming Langmuir adsorption model, which suits for biosorption with Scenedesmus and other microalgae. At these low concentrations, the metal ions listed in Table 1 are at a disadvantage to compete with other ions present in the solutions for the metal binding sites. Still, we cannot rule out that the residual elements may be chemically bound to soluble organic molecules excreted by the algae, making them not available for passive adsorption. This set of results indicates that both passive and active mechanism of metal removal may occur by in vivo Scenedesmus growth on treated AMD, even though quantitative values were not determined and this would be the subject of investigation on the continuity of this study. Although there was no significant difference in metal removal, the addition of nutrients enhances the biomass growth, which can be interesting from another perspective. The use of nutrients should be considered in scenarios where algae biomass can be used as raw material for the production of biofuel and biofertilizers [28,41,42].
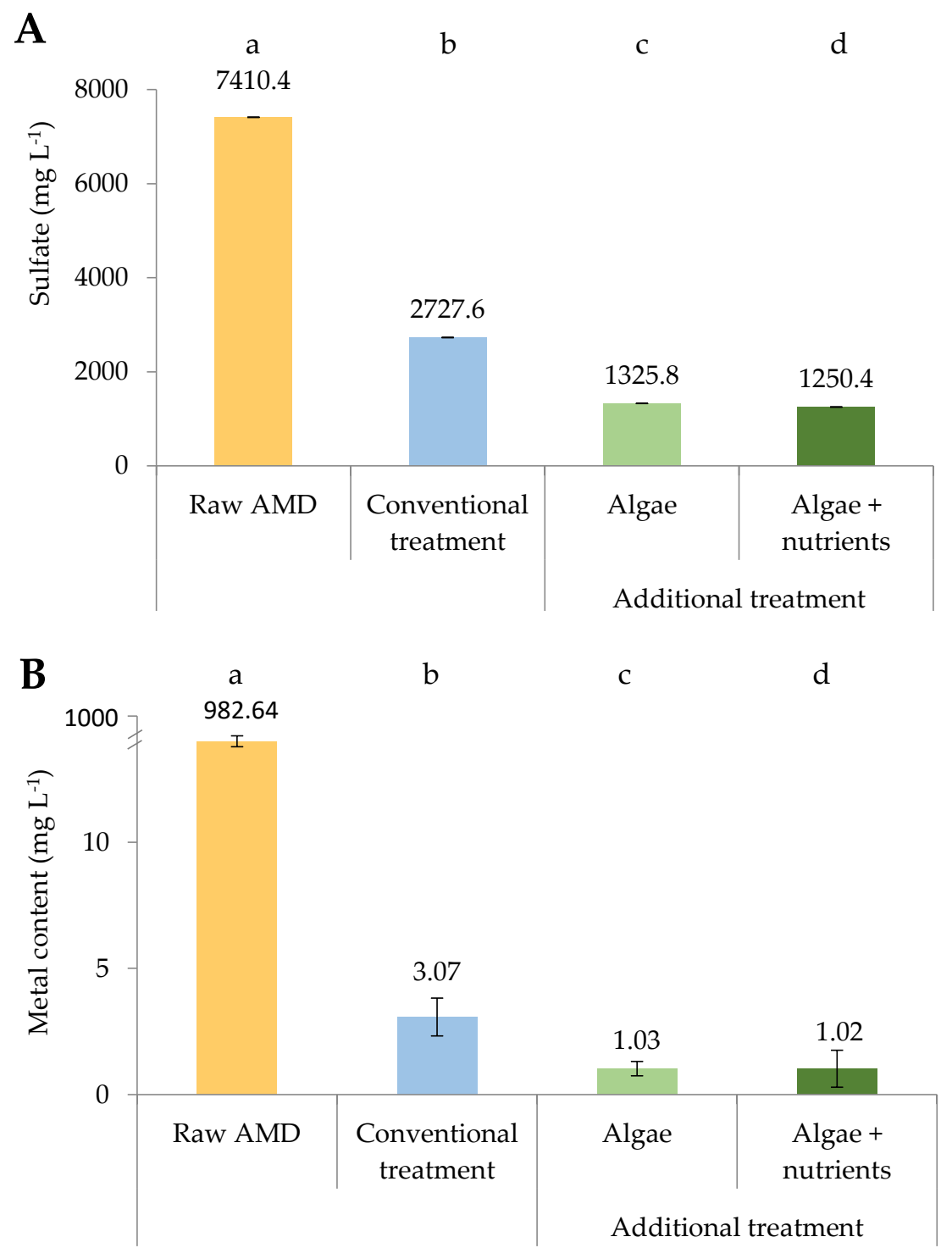

Figure 3. Comparison between raw AMD, conventional and additional treatments in terms of sulfate (A) and metal content (B). Means that differ significantly (Tukey's test, $p<0.05$ ) are indicated by different lowercase letters.

Nevertheless, although physical-chemical analysis is important to attend the legal framework for effluent discharge, they do not predict toxicity to living organisms. The environmental effects and 
behavior of substances should also be evaluated by biological assays [43,44]. In this specific work, it was carried out with the toxicological bio-indicators Allium cepa (onion) and Daphnia magna.

The toxicity results with Allium cepa were based on relative growth, inhibition, and germination indices of the roots (Table 2). In raw AMD, it was possible to observe the total inhibition in onion root growth, probably due to the high acidity of the medium and high metal concentrations. These values are in accordance with the study of Geremias et al. [45], which also suggested that the phytotoxic effect could be associated with low $\mathrm{pH}$ values $(\mathrm{pH}=2.5)$ and the expressive concentration of metals such as iron, aluminum, manganese, zinc, and lead, present in the effluent, that could be incorporated by the plant. After conventional chemical treatment with $\mathrm{Ca}(\mathrm{OH})_{2}$ at $\mathrm{pH} 8.7$, the effluent was non-toxic. There was an adequate root growth, both in length and mass, being in fact superior to the control (negative II values). Similar results were attained for the effluent after the additional treatment step with algae. In other words, the polishing step with algae did not modify the behavior of the onion root growth, either negatively or positively. Regarding the germination index, according to the classification adopted by Zucconi et al. [46], it was also not possible to observe a difference between treatments, which were classified as absent or low toxicity.

Table 2. Relative growth index (RGI), inhibition index (II), germination (G) and germination indices (GI) of Allium cepa roots for control $\left(\mathrm{H}_{2} \mathrm{O}\right)$; raw AMD; AMD after conventional treatment; and AMD after additional treatment with algae without and with nutrients addition.

\begin{tabular}{|c|c|c|c|c|c|c|}
\hline & RGI & II (\%) & Toxicity & G (\%) & GI (\%) & Toxicity \\
\hline Raw AMD & 0 & 100 & Inhibition & 0 & 0 & High \\
\hline Conventional treatment & 1.37 & -37 & Stimulation & 71 & 97 & Absent or low \\
\hline \multicolumn{7}{|c|}{ Additional treatment } \\
\hline Algae & 1.16 & -17 & No significant effect & 74 & 86 & Absent or low \\
\hline Algae + nutrients & 1.32 & -32 & Stimulation & 90 & 119 & Absent or low \\
\hline
\end{tabular}

Toxicity criterion (II): inhibition-RGI between 0 and 0.8 , no significant effect-RGI between 0.8 and 1.2 , stimulation-RGI greater than 1.2. Toxicity criterion (GI)—absent or low toxicity-GI greater than $80 \%$, moderate toxicity-GI between 50 and $80 \%$; high toxicity-GI less than $50 \%$.

Table 3 shows the results obtained for the acute toxicity tests for the Daphnia magna microcrustaceans exposed to raw AMD, and the respective treatments by conventional and additional treatment with biosorption of algae Scenedesmus sp. The toxicity results show that raw acid drainage presented a toxicity factor (TF) of 400 and concentration of effect at 50\% of the population (CE-50) of $6.25 \%$, which classified it as an extremely toxic effluent. Similar results were presented by Kang et al. [47], who showed that acid mine drainage is highly toxic to microcrustaceans. This high toxicity may be due to the acidic $\mathrm{pH}$, considerably below the no effect $\mathrm{pH}$ range for Daphnia magna ( $\mathrm{pH}$ 4-11.5), and the high concentration of metals $[48,49]$. After conventional treatment, the TF values improved to 4 , and the CE-50 was greater than $100 \%$, classifying the samples as slightly toxic. The remaining toxic effect may be related to the Mn and As concentrations still present after treatment, since the studied species has sensitivity to these metals [50,51]. It may also be related to the conductivity, since the organism is sensitive to conductivity values greater than $2 \mathrm{mS} \mathrm{cm}^{-1}$ [52]. After the additional treatment with algae, there was another noticeable decrease in FT, reaching the value of 2 for both situations considered-with and without nutrients addition. The CE-50 was greater than $100 \%$, framing it as slightly toxic.

The results show that microalgae may be suitable candidates for simultaneous remediation and sustainable biomass production in aqueous environments fed by treated acid mine drainage-at least from those of the coal mining industry. These efforts may help to attain the environmental standards that regulate the mining sector $[53,54]$ and to contribute to the existing tendency of the mineral sector to look for sustainable practices, such as zero waste emission or further use of residual materials according to the economic model of the circular economy $[55,56]$. 
Table 3. Toxicity assays for Daphnia Magna microcrustaceans exposed to raw AMD; AMD after conventional treatment; and AMD after additional treatment with algae, with and without nutrients addition.

\begin{tabular}{cccc}
\hline & TF & CE-50 $\mathbf{4 8 ~ h ~ ( \% )}$ & Toxicity \\
\hline Raw AMD & 400 & 6.25 & Extremely toxic \\
Conventional treatment & 4 & $>100$ & Slightly toxic \\
Algae & Additional treatment & \\
Algae + nutrients & 2 & $>100$ & Slightly toxic \\
\hline
\end{tabular}

Toxicity criterion: extremely toxic-CE-50<25\%, highly toxic-CE-50 between 25 and $50 \%$, moderately toxic-CE-50 between 50 and $65 \%$, and slightly toxic-CE-50 $>65 \%$ [46].

\section{Conclusions}

The biosorption process with the in vivo microalgae Scenedesmus sp proved to be efficient as a polishing step in AMD treatment systems considering both physical-chemical and toxicological analyses. After 10 days of algal growth, the Scenedesmus sp biomass (on a dry basis) concentration can reach $230 \mathrm{mg} \mathrm{L}^{-1}$ without the use of nutrients, and $650 \mathrm{mg} \mathrm{L}^{-1}$ with the addition of nutrients. Regardless of the use or not of nutrients, the biosorption process contributed significantly to reducing the total metal and sulfate content, as well as the conductivity.

Concerning the toxicological studies, the organisms tested in this work proved to be suitable as bioindicators to evaluate the performance of AMD treatment procedures in coal mining, each one presenting certain particularity. The growth of Allium cepa roots presented the advantage of a simple test and allowed a differentiation between treated and untreated AMD, but showed a low sensitivity among the various treatment scenarios. The acute toxicity test with Daphnia magna showed a higher sensitivity, allowing the differentiation of results between the raw and treated AMD, as well as between the different types of treatment applied.

Author Contributions: K.B.d.S.: Conceptualization, Investigation, Formal analysis, Writing-original draft. V.O.d.A.: Formal analysis, Investigation. J.W.: Investigation, Writing—original draft, Writing—review \& editing. I.A.H.S.: Conceptualization, Formal analysis, Resources, Writing-review \& editing. All authors have read and agreed to the published version of the manuscript.

Funding: This research was funded by Coordenação de Aperfeiçoamento de Pessoal de Nível Superior (CAPES) grant number [88882.345791/2019-01] and Conselho Nacional de Desenvolvimento Científico e Tecnológico (CNPQ) grant number [310369/2016-9] and [160570/2019-0].

Acknowledgments: This work was supported by the following Brazilian funding agencies: Coordenação de Aperfeiçoamento de Pessoal de Nível Superior (CAPES) and Conselho Nacional de Desenvolvimento Científico e Tecnológico (CNPQ). The authors are also grateful to Jean Carlo Salomé dos Santos Menezes for providing AMD samples.

Conflicts of Interest: The authors declare no conflict of interest.

\section{References}

1. Kontopoulos, A. Acid mine drainage control. In Effluent Treatment in the Mining Industry; Castro, S.H., Vergara, F.S.M.A., Eds.; University of Concepciòn: Concepción, Chile, 1998; pp. 57-118. ISBN 956-227-156-0.

2. Skousen, J.; Rose, A.; Geidel, G.; Foreman, J.; Evans, R.; Hellier, W. Handbook of Technologies for Avoidance and Remediation of Acid Mine Drainage. Available online: https://wvwri.wvu.edu/files/d/c2e42b2b-e40d4ada-8bad-3c264d867e76/99-handbook-avoidance-remediation.pdf (accessed on 24 June 2020).

3. Kefeni, K.K.; Msagati, T.A.M.; Mamba, B.B. Acid mine drainage: Prevention, treatment options, and resource recovery: A review. J. Clean. Prod. 2017, 151, 475-493. [CrossRef]

4. Skousen, J.G.; Ziemkiewicz, P.F.; McDonald, L.M. Acid mine drainage formation, control and treatment: Approaches and strategies. Extr. Ind. Soc. 2019, 6, 241-249. [CrossRef]

5. Silveira, A.N.; Silva, R.; Rubio, J. Treatment of acid mine drainage (AMD) in South Brazil: Comparative active processes and water reuse. Int. J. Miner. Process. 2009, 93, 103-109. [CrossRef] 
6. Santos, K.B.; Almeida, V.O.; Weiler, J.; Menezes, J.C.S.S.; Schneider, I.A.H. Ecotoxicity with Allium cepa to determine the efficiency of conventional ARD treatment by neutralization/precipitation from a brazilian coal mine. Proc. IMWA 2019, 269-274.

7. Pereira, T.C.B.; dos Santos, K.B.; Lautert-Dutra, W.; de Souza Teodoro, L.; de Almeida, V.O.; Weiler, J.; Schneider, I.A.H.; Bogo, M.R. Acid mine drainage (AMD) treatment by neutralization: Evaluation of physical-chemical performance and ecotoxicological effects on zebrafish (Danio rerio) development. Chemosphere 2020, 253, 126665. [CrossRef]

8. Freitas, A.P.P.; Schneider, I.A.H.; Schwartzbold, A. Biosorption of heavy metals by algal communities in water streams affected by the acid mine drainage in the coal-mining region of Santa Catarina state, Brazil. Miner. Eng. 2011, 24, 1215-1218. [CrossRef]

9. Bwapwa, J.K.; Jaiyeola, A.T.; Chetty, R. Bioremediation of acid mine drainage using algae strains: A review. South Afr. J. Chem. Eng. 2017, 24, 62-70. [CrossRef]

10. Edmundson, S.J.; Wilkie, A.C. Landfill leachate-A water and nutrient resource for algae-based biofuels. Environ. Technol. 2013, 34, 1849-1857. [CrossRef] [PubMed]

11. Leite, G.B.; Abdelaziz, A.E.M.; Hallenbeck, P.C. Algal biofuels: Challenges and opportunities. Bioresour. Technol. 2013, 145, 134-141. [CrossRef] [PubMed]

12. Ghorbani, A.; Rahimpour, M.R.; Ghasemi, Y.; Raeissi, S. The biodiesel of microalgae as a solution for diesel. Energies 2018, 11, 950. [CrossRef]

13. Wei, X.; Viadero, R.C.; Buzby, K.M. Recovery of iron and aluminum from acid mine drainage by selective precipitation. Environ. Eng. Sci. 2005, 22, 745-755. [CrossRef]

14. Chen, T.; Yan, B.; Lei, C.; Xiao, X. Pollution control and metal resource recovery for acid mine drainage. Hydrometallurgy 2014, 12, 147-148. [CrossRef]

15. Hedrich, S.; Johnson, D.B. Remediation and selective recovery of metals from acidic mine waters using novel modular bioreactors. Environ. Sci. Technol. 2014, 48, 12206-12212. [CrossRef]

16. Menezes, J.C.S.S.; Silva, R.A.; Arce, I.S.; Schneider, I.A.H. Production of a poly-ferric sulphate chemical coagulant by selective precipitation of iron from acidic coal mine drainage. Mine Water Environ. 2009, 28, 311-314. [CrossRef]

17. Menezes, J.C.S.S.; Silva, R.A.; Arce, I.S.; Schneider, I.A.H. Production of a poly-alumino-iron sulphate coagulant by chemical precipitation of a coal mining acid drainage. Miner. Eng. 2010, 23, 249-251. [CrossRef]

18. Silva, R.D.A.; Castro, C.D.; Vigânico, E.M.; Petter, C.O.; Schneider, I.A.H. Selective precipitation/UV production of magnetite particles obtained from the iron recovered from acid mine drainage. Miner. Eng. 2012, 29, 22-27. [CrossRef]

19. Silva, R.D.A.; dos Santos Menezes, J.C.S.; Lopes, F.A.; Kirchheim, A.P.; Schneider, I.A.H. Synthesis of a goethite pigment by selective precipitation of iron from acidic coal mine drainage. Mine Water Environ. 2017, 36, 386-392. [CrossRef]

20. Macías, F.; Pérez-López, R.; Caraballo, M.A.; Cánovas, C.R.; Nieto, J.M. Management strategies and valorization for waste sludge from active treatment of extremely metal-polluted acid mine drainage: A contribution for sustainable mining. J. Clean. Prod. 2017. [CrossRef]

21. De AlmeidaSilva, R.; Secco, M.P.; Lermen, R.T.; Schneider, I.A.H.; Hidalgo, G.E.N.; Sampaio, C.H. Optimizing the selective precipitation of iron to produce yellow pigment from acid mine drainage. Miner. Eng. 2019, 141, 1057-1066. [CrossRef]

22. Akinwekomi, V.; Maree, J.P.; Masindi, V.; Zvinowanda, C.; Osman, M.S.; Foteinis, S.; Mpenyana-Monyatsi, L.; Chatzisymeon, E. Beneficiation of acid mine drainage (AMD): A viable option for the synthesis of goethite, hematite, magnetite, and gypsum-Gearing towards a circular economy concept. Miner. Eng. 2020, 148, 106204. [CrossRef]

23. Bonnélye, V. Acid Mine Drainage: Case Study of One of the Largest Copper Mine Sites in the World, Ozwater15. Available online: https://pdfs.semanticscholar.org/4909/b6b7814b58c391ea9c54306bb9b7c4c834c4. pdf (accessed on 6 August 2020).

24. Chesters, S.P.; Morton, P.; Fazel, M. Membranes and minewater-waste or revenue stream. In Proceedings of the IMWA 2016 - Mining Meets Water - Conflicts and Solutions, Leipzig, Germany; 11-15 2016; pp. 1310-1322.

25. Cheng, S.; Dempsey, B.A.; Logan, B.E. Electricity generation from synthetic acid-mine drainage (AMD) water using fuel cell technologies. Environ. Sci. Technol. 2007, 41, 8149-8153. [CrossRef] [PubMed] 
26. Palma, H.; Killoran, E.; Sheehan, M.; Berner, F.; Heimann, K. Assessment of microalga biofilms for simultaneous remediation and biofuel generation in mine tailings water. Bioresour. Technol. 2017, 234, 327-335. [CrossRef]

27. Urrutia, C.; Yañez-Mansilla, E.; Jeison, D. Bioremoval of heavy metals from metal mine tailings water using microalgae biomass. Algal Res. 2019, 43, 101659. [CrossRef]

28. Abinandan, S.; Subashchandrabose, S.R.; Venkateswarlu, K.; Megharaj, M. Sustainable iron recovery and biodiesel yield by acid-adapted microalgae, Desmodesmus sp. MAS1 and Heterochlorella sp. MAS3, grown in synthetic acid mine drainage. ACS Omega 2020, 5, 6888-6894. [CrossRef]

29. Levandowski, J.; Kalkreuth, W. Chemical and petrographical characterization of feed coal, fly ash and bottom ash from the Figueira Power Plant, Paraná, Brazil. Int. J. Coal Geol. 2009, 77, 269-281. [CrossRef]

30. Campaner, V.P.; Luiz-Silva, W.; Machado, W. Geochemistry of acid mine drainage from a coal mining area and processes controlling metal attenuation in stream waters, southern Brazil. An. Acad. Bras. Cienc. 2014, 86, 539-544. [CrossRef]

31. Mehta, S.K.; Gaur, J.P. Use of algae for removing heavy metal ions from wastewater: Progress and prospects. Crit. Rev. Biotechnol. 2005, 25, 113-152. [CrossRef]

32. Guillard, R.R.L. Culture of phytoplankton for feeding marine invertebrates. In Culture of Marine Invertebrate Animals; Smith, W.L., Chanley, H.H., Eds.; Plenum Press: New York, NY, USA, 1975; pp. $29-60$.

33. Eaton, A.D.; Clesceri, L.S.; Rice, E.; Greenbaerg, A.E.; Franson, M.A.H. Standard Methods for Examination of Water and Wastewater, 21th ed.; American Public Health Association: Washington DC, USA, 15 October 2005.

34. Fiskesjö, G. The Allium test-An alternative in environmental studies: The relative toxicity of metal ions. Mutat. Res. Fundam. Mol. Mech. Mutagen. 1988, 197, 243-260. [CrossRef]

35. OECD. Test No. 202: Daphnia sp. Acute Immobilisation Test, OECD Guidelines for the Testing of Chemicals, Section 2; OECD Publishing: Paris, France, 2004. [CrossRef]

36. Edition, F. Methods for Measuring the Acute Toxicity of Effluents and Receiving Waters to Freshwater and Marine Organisms, 5th ed.; US Environmental Protection Agency US EPA: Washington, DC, USA, 2002; Volume 232, p. 266.

37. Ministério do Meio Ambiente, Conselho Nacional do Meio Ambiente, Brasil. Resolução CONAMA n $n^{\circ} 430 / 2011$; Conselho Nacional do Meio Ambiente, Ministério do Meio Ambiente, Brasil: PBrasília, Brazil, 2011.

38. Santos, K. Tratamento de drenagem ácida de minas por neutralização/precipitação-efeito do $\mathrm{pH}$, agente neutralizante e tratamento complementar por biossorção com microalgas. Master's Thesis, Universidade Federal do Rio Grande do Sul, Porto Alegre, Brazil, 2020.

39. Kumar, K.S.; Dahms, H.U.; Won, E.J.; Lee, J.S.; Shin, K.H. Microalgae-A promising tool for heavy metal remediation. Ecotoxicol. Environ. Saf. 2015, 113, 329-352. [CrossRef] [PubMed]

40. Dönmez, G.Ç.; Aksu, Z.; Öztürk, A.; Kutsal, T. A comparative study on heavy metal biosorption characteristics of some algae. Process Biochem. 1999, 34, 885-892. [CrossRef]

41. Priyadarshani, I.; Rath, B. Commercial and industrial applications of micro algae-A review. J. Algal Biomass Utln. 2012, 3, 89-100.

42. Mehrabadi, A.; Craggs, R.; Farid, M.M. Wastewater treatment high rate algal ponds (WWT HRAP) for low-cost biofuel production. Bioresour. Technol. 2015, 184, 202-214. [CrossRef]

43. Chamorro, S.; Barata, C.; Piña, B.; Casado, M.; Schwarz, A.; Sáez, K.; Vidal, G. Toxicological analysis of acid mine drainage by water quality and land use bioassays. Mine Water Environ. 2018, 37, 88-97. [CrossRef]

44. Yim, J.H.; Kim, K.W.; Kim, S.D. Effect of hardness on acute toxicity of metal mixtures using Daphnia magna: Prediction of acid mine drainage toxicity. J. Hazard. Mater. 2006, 138, 16-21. [CrossRef]

45. Geremias, R.; Bortolotto, T.; Wilhelm-Filho, D.; Pedrosa, R.C.; de Fávere, V.T. Efficacy assessment of acid mine drainage treatment with coal mining waste using Allium cepa L. as a bioindicator. Ecotoxicol. Environ. Saf. 2012, 79, 116-121. [CrossRef]

46. Zucconi, F.; Forte, M.; Monaco, A.; De Bertoldi, M. Biological evaluation of compost maturity. Biocycle 1981, 22, 27-29.

47. Kang, S.W.; Seo, J.; Han, J.; Lee, J.S.; Jung, J. A comparative study of toxicity identification using Daphnia magna and Tigriopus japonicus: Implications of establishing effluent discharge limits in Korea. Mar. Pollut. Bull. 2011, 63, 370-375. [CrossRef] 
48. Arambašić, M.B.; Bjelić, S.; Subakov, G. Acute toxicity of heavy metals (copper, lead, zinc), phenol and sodium on Allium cepa L., Lepidium sativum L. and Daphnia magna St.: Comparative investigations and the practical applications. Water Res. 1995, 29, 497-503. [CrossRef]

49. Seco, J.I.; Fernández-Pereira, C.; Vale, J. A study of the leachate toxicity of metal-containing solid wastes using Daphnia magna. Ecotoxicol. Environ. Saf. 2003, 56, 339-350. [CrossRef]

50. Soucek, D.J.; Cherry, D.S.; Trent, G.C. Relative acute toxicity of acid mine drainage water column and sediments to Daphnia magna in the Puckett's Creek watershed, Virginia, USA. Arch. Environ. Contam. Toxicol. 2000, 38, 305-310. [CrossRef] [PubMed]

51. De Bisthoven, L.J.; Gerhardt, A.; Soares, A.M.V.M. Chironomidae larvae as bioindicators of an acid mine drainage in Portugal. Hydrobiologia 2005, 532, 181-191. [CrossRef]

52. Benzie, J.A.H. Cladocera: The Genus DAPHNIA (including DAPHNIOPSIS) (Anomopoda: Daphniidae). Guides to the Identification of the Microinvertebrates of the Continental Waters of the World. Q. Rev. Biol. 2005, 21. [CrossRef]

53. Thomashausen, S.; Maennling, N.; Mebratu-Tsegaye, T. A comparative overview of legal frameworks governing water use and waste water discharge in the mining sector. Resour. Policy 2018, 55, 143-151. [CrossRef]

54. Rezaie, B.; Anderson, A. Sustainable resolutions for environmental threat of the acid mine drainage. Sci. Total Environ. 2020, 717, 137211. [CrossRef]

55. Ellen MacArthur Foundation. Towards the Circular Economy-Economic and Business Rationale for an Accelerated Transition; Available online: https:/www.ellenmacarthurfoundation.org/publications/ towards-the-circular-economy-vol-1-an-economic-and-business-rationale-for-an-accelerated-transition (accessed on 6 August 2020).

56. Singh, S.; Sukla, L.B.; Goyal, S.K. Mine waste \& circular economy. Mater. Today Proc. 2020, 1-8. [CrossRef]

(C) 2020 by the authors. Licensee MDPI, Basel, Switzerland. This article is an open access article distributed under the terms and conditions of the Creative Commons Attribution (CC BY) license (http://creativecommons.org/licenses/by/4.0/). 